\title{
Sponge delivery variables and tissue levels of 5-fluorouracil
}

\author{
Mark R Wilkins, Nicholas L Occleston, Aachal Kotecha, Lorraine Waters, Peng T Khaw
}

\begin{abstract}
Aim-To study how the delivery of 5-fluorouracil (5-FU) to ocular tissues is affected by altering delivery variables. Method-Sponge(s) soaked in radiolabelled 5-FU were placed between the conjunctiva and sclera of pig eyes. Application time, sponge size, sponge make (Altomed, Weck, Merocel), and 5-FU concentration were varied. Conjunctival and scleral tissue levels were determined in samples taken from the application site.

Results-Dose-response curves for scleral and conjunctival 5-FU levels against application time showed increasing tissue levels that reached a plateau after 2-3 minutes. Application beyond 3 minutes did not increase tissue levels. There was no difference in tissue levels between $7 \times 4$ and $3.5 \times 2$ $\mathrm{mm}$ sponges. Altomed sponges produced 5-FU tissue levels that were twice as high as those obtained with Weck-cell $(p<0.01)$ or Merocel $(p<0.02)$ sponges. Changing the 5 -FU concentration from $25 \mathrm{mg} / \mathrm{ml}$ to 6.25 $\mathrm{mg} / \mathrm{ml}$ reduced the conjunctival concentration by a factor of $3.5(\mathrm{p}<0.003)$.

Conclusion-Application time up to 3 minutes, sponge make, and 5-FU concentration can have a large effect on the tissue delivery of 5-FU. Application time beyond 3 minutes, using $3.5 \times 2 \mathrm{~mm}$ or $7 \times 4 \mathrm{~mm}$ sponges, and replacing sponges every minute did not have a significant effect on tissue levels. This study models the effect that different variables can have on the ocular tissue levels of an antimetabolite applied intraoperatively.

(Brf Ophthalmol 2000;84:92-97)
\end{abstract}

Research Unit,

Department of

Pathology, Institute of

Ophthalmology,

London

M R Wilkins

$\mathrm{N}$ L Occleston

A Kotecha

L Waters

P T Khaw

Glaucoma Unit,

Moorfields Eye

Hospital, London

M R Wilkins

A Kotecha

P T Khaw

Correspondence to: Mr Peng T Khaw, Wound Healing Research Unit, Department of Pathology, Institute of Ophthalmology, Bath Street, London, EC1V 9EL

Accepted for publication 18 August 1999 varying duration of application, ${ }^{13-15}$ concentration of agent, ${ }^{13}{ }^{16-18}$ and irrigation, ${ }^{19}$ but not sponge type or treatment area. Non-clinical studies have altered sponge type ${ }^{20}$ and area. ${ }^{21}$ We designed a study to investigate the effects of application time, application technique, sponge type, and size on tissue levels of 5-FU in an experimental model.

\section{Method}

Fresh pig eyes (Dalehead Foods, Cambridgeshire) were removed from carcasses on the morning of slaughter and transported to the laboratory. Dissolving a pellet of ${ }^{14} \mathrm{C} 5-\mathrm{FU}$ (Sigma) in $2 \mathrm{ml}$ distilled water made up a stock solution of ${ }^{14} \mathrm{C}$ labelled 5-FU. For each application technique, adding $5 \mu \mathrm{l}$ of stock to 3 $\mathrm{ml}$ of $25 \mathrm{mg} / \mathrm{ml} \mathrm{5-FU} \mathrm{(David} \mathrm{Bull} \mathrm{Laborato-}$ ries) created a radioactive 5-FU solution. Preliminary work showed that this dilution was sufficient to produce detectable levels in ocular tissue following application.

Each eye that was tested was placed under an operating microscope and rotated until undisturbed conjunctiva overlying sclera was visible superiorly. A limbal based flap was dissected and, depending on the experiment, one or more sponges soaked in ${ }^{14} \mathrm{C} 5-\mathrm{FU}$ placed between the conjunctiva and sclera. For techniques $1-4$ a $25 \mathrm{mg} / \mathrm{ml}{ }^{14} \mathrm{C} 5-\mathrm{FU}$ solution as detailed above was used. For technique 5 the solution was diluted 1:4 using phosphate buffered saline. The posterior edge of the conjunctiva was held down using a muscle clamp. The following application techniques were then performed:

(1) Single $7 \times 4 \mathrm{~mm}$ Altomed sponge applied for $0,1,2,3,5$, and 10 minutes.

(2) Single $3.5 \times 2 \mathrm{~mm}$ Altomed sponge applied for 5 minutes, compared with single $7 \times 4$ $\mathrm{mm}$ Altomed sponge applied for 5 minutes.

(3) $7 \times 4 \mathrm{~mm}$ Altomed sponge: one sponge applied for 1 minute replaced every minute for 5 minutes, compared with single $7 \times 4 \mathrm{~mm}$ Altomed sponge applied for 5 minutes.

(4) Single Merocel, Weck, or Altomed $7 \times 4$ mm sponge applied for 5 minutes.

(5) Single $7 \times 4 \mathrm{~mm}$ Altomed sponge soaked in $6.25 \mathrm{mg} / \mathrm{ml}{ }^{14} \mathrm{C}$ labelled $5-\mathrm{FU}$ solution applied for 5 minutes, compared with single $7 \times 4 \mathrm{~mm}$ Altomed sponge soaked in 25 $\mathrm{mg} / \mathrm{ml}{ }^{14} \mathrm{C}$ labelled $5-\mathrm{FU}$ solution applied for 5 minutes.

Following the application all sponges were removed and the treated area irrigated with 20 $\mathrm{ml}$ phosphate buffered saline. Conjunctiva overlying the treated area was removed from all eyes using an $8.25 \mathrm{~mm}$ corneal trephine. Additional scleral samples were taken from groups 1 to 3. Sclera underlying the treated area was removed using an $8.25 \mathrm{~mm}$ trephine. To assess 


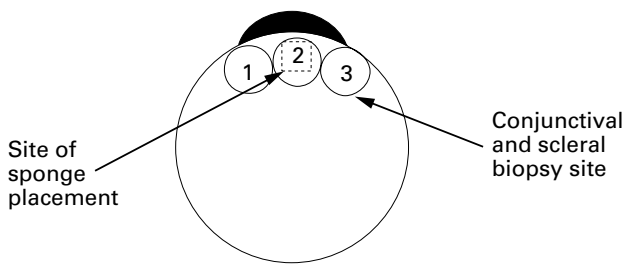

Figure 1 Sites of conjunctival and scleral biopsies. Box shows site of sponge application.

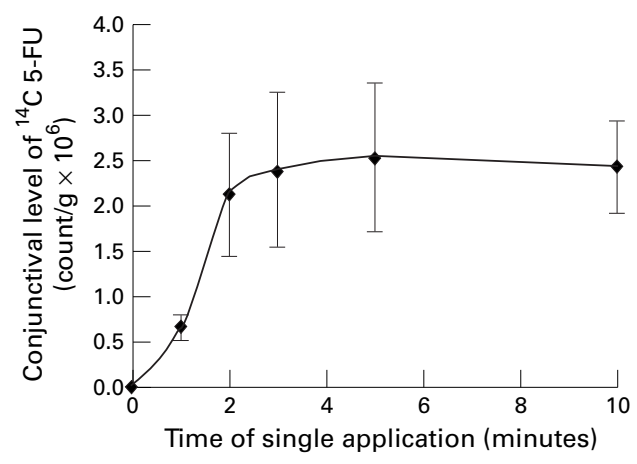

Figure 2 Conjunctival tissue level of ${ }^{14} \mathrm{C} 5-\mathrm{FU}$ against duration of single application of Altomed sponge.

regional tissue 5-FU levels conjunctival and scleral trephines were taken from either side of the treated area (Fig 1) after single 5 minute applications of $7 \times 4 \mathrm{~mm}$ and $3.5 \times 4 \mathrm{~mm}$ Altomed sponges. Five fresh eyes were used for each change in application time, technique, or sponge type. Altomed sponges were supplied

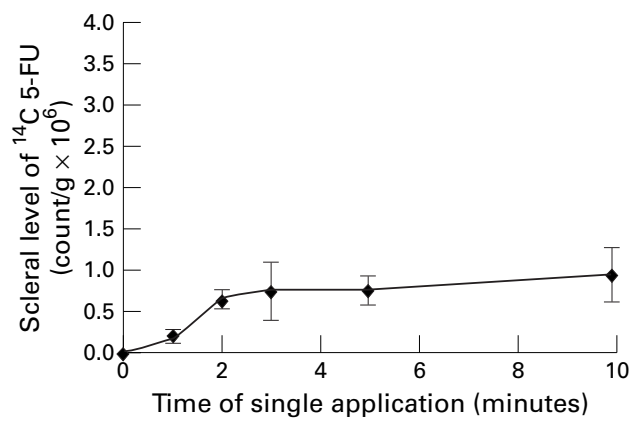

Figure 3 Scleral tissue level of ${ }^{14} \mathrm{C} 5-\mathrm{FU}$ against duration of single application of Altomed sponge.

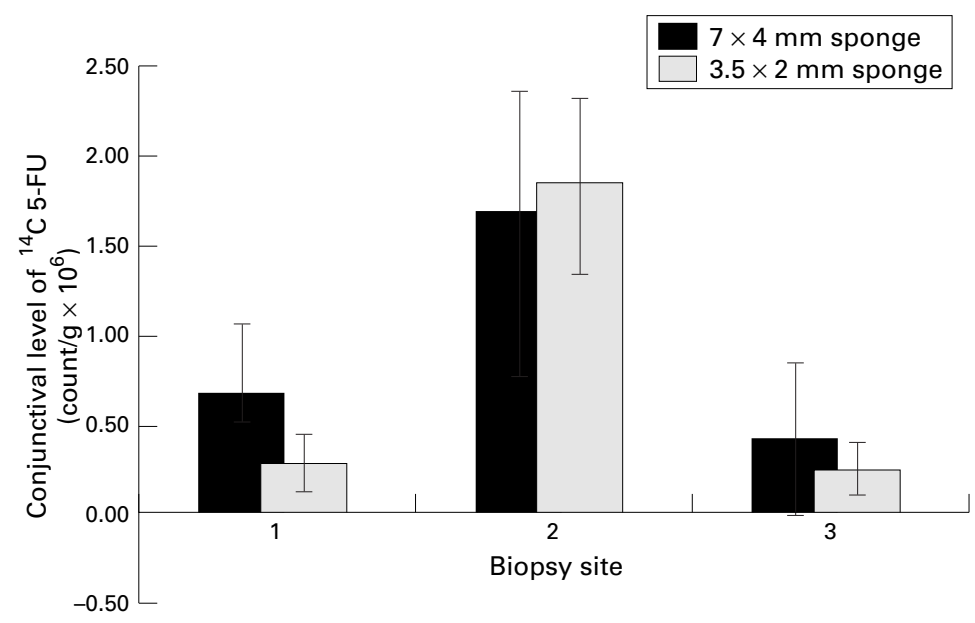

Figure 4 Regional conjunctival tissue level of ${ }^{14} \mathrm{C} 5-\mathrm{FU}$ following single 5 minute application of either $7 \times 4 \mathrm{~mm}$ or $3.5 \times 2 \mathrm{~mm}$ Altomed sponge. Sites 1, 2, and 3 are shown in Figure 1. as $7 \mathrm{~mm}$ wide strips. These were cut into $4 \mathrm{~mm}$ wide pieces using a purpose made punch. ${ }^{22}$ Weck and Merocel sponges were supplied on wider strips that were reduced to $7 \mathrm{~mm}$ in width and then passed through the same punch. Quartering $7 \times 4 \mathrm{~mm}$ sponges produced the $3.5 \times 2 \mathrm{~mm}$ sponges.

Each trephined tissue sample was placed in a preweighed scintillation vial that was then weighed again to calculate the weight of the specimen. Two $\mathrm{ml}$ of Soluene (CambridgePackard) were added to the vial. The vial was then incubated at $37^{\circ} \mathrm{C}$ overnight to encourage the tissue to dissolve. After the tissue had dissolved, $10 \mathrm{ml}$ of Hionic-fluor (CambridgePackard) was added and the vial then passed through a Cambridge-Packard scintillation counter. The resulting count was divided by the tissue weight to achieve a count per gram of tissue. This was taken to be directly proportional to the amount of 5-FU absorbed by the tissue.

\section{Results}

DURATION OF APPLICATION-A SINGLE ALTOMED SPONGE APPLIED FOR INCREASING TIME PERIODS (FIGS 2 AND 3)

A dose-response curve for 5-FU tissue levels in both sclera and conjunctiva is shown. The changes in tissue levels are significant using one way analysis of variance (conjunctiva $\mathrm{p}<0.001$, scleral $\mathrm{p}<0.001)$. Both curves show little improvement in tissue levels beyond a 3 minute single application. There was no significant difference between the $2,3,5$, and 10 minute ${ }^{14} \mathrm{C} 5-\mathrm{FU}$ conjunctival and scleral levels. There was marked variability in the conjunctival tissue levels beyond 1 minute. A Levene test for homogeneity of variance across the time points was significant for the conjunctival tissue levels $(p=0.02)$ but not for the scleral ones $(p=0.056)$. The Levene test, which is not dependent on the assumption of normality, assesses the equality of group variances. A significant value for the conjunctival tissue levels suggests that there were real differences in the variance at different time points.

SPONGE AREA-A SINGLE $7 \times 4$ MM ALTOMED SPONGE $V$ A SINGLE $3.5 \times 2$ MM ALTOMED SPONGE, BOTH APPLIED FOR 5 MINUTES (FIGS 4 AND 5)

There was no significant difference in scleral and conjunctival ${ }^{14} \mathrm{C} 5-\mathrm{FU}$ levels at the application site with the two sponge sizes. There was a marked fall off in scleral and conjunctival tissue levels either side of the application site which was significant whether a $7 \times 4$ $\mathrm{mm}$ or $3.5 \times 2 \mathrm{~mm}$ sponge was used.

SPONGE REPLACEMENT-A SINGLE ALTOMED SPONGE APPLIED FOR 5 MINUTES COMPARED WITH REPLACING THE SPONGE EVERY MINUTE FOR 5 MINUTES (FIGS 6 AND 7)

Replacing the sponge every minute did not significantly increase either conjunctival or scleral ${ }^{14} \mathrm{C}$ 5-FU levels.

SPONGE TYPE— 5 MINUTE SINGLE APPLICATIONS OF THREE SPONGE TYPES (FIG 8)

Mean conjunctival tissue levels of ${ }^{14} \mathrm{C} 5-\mathrm{FU}$ were significantly different across the three 


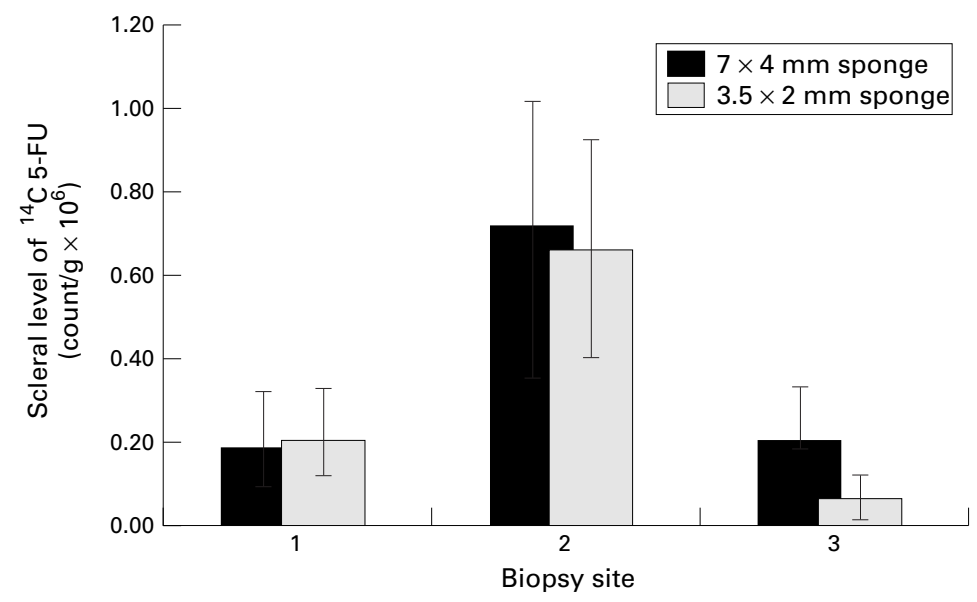

Figure 5 Regional scleral tissue level of ${ }^{14} \mathrm{C} 5-\mathrm{FU}$ following single 5 minute application of either $7 \times 4 \mathrm{~mm}$ or $3.5 \times 2 \mathrm{~mm}$ Altomed sponge. Sites 1,2, and 3 are shown in Figure 1.

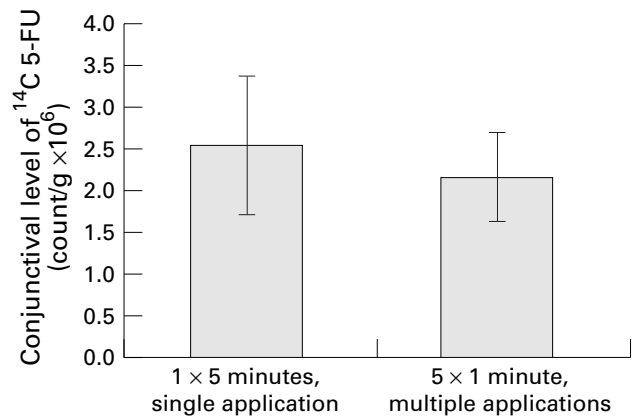

Figure 6 Conjunctival tissue level of ${ }^{14} \mathrm{C} 5-\mathrm{FU}$ following either a single Altomed sponge applied for 5 minutes or an Altomed sponge replaced every minute for 5 minutes.

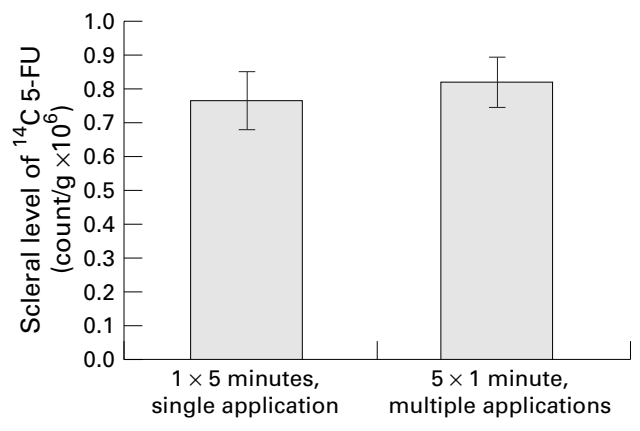

Figure 7 Scleral tissue level of ${ }^{14} \mathrm{C} 5-\mathrm{FU}$ following either a single Altomed sponge applied for 5 minutes or an Altomed sponge replaced every minute for 5 minutes

sponge types (one way ANOVA $\mathrm{p}=0.005$ ). Mean conjunctival tissue levels following application using an Altomed sponge were at least double those using Weck-cell or Merocel sponges. (Weck-cell $v$ Altomed $\mathrm{p}=0.01$, Merocel $v$ Altomed $p=0.02)$. Using the Levene test for homogeneity of variance showed that the variance of tissue distribution was not the same for each sponge type $p=0.039$.

TECHNIQUE 5 CONCENTRATION (FIGS 9 AND 10) - SINGLE 5 MINUTE APPLICATION OF A $7 \times 4 \mathrm{MM}$ ALTOMED SPONGE SOAKED IN EITHER $25 \mathrm{MG} / \mathrm{ML}$ OR $6.25 \mathrm{MG} / \mathrm{ML}{ }^{14} \mathrm{C} 5$-FU

Reducing the concentration by a factor of 4 reduced the conjunctival ${ }^{14} \mathrm{C}$ 5-FU tissue levels by a factor of 3.5 ( $t$ test $\mathrm{p}=0.003$ ).

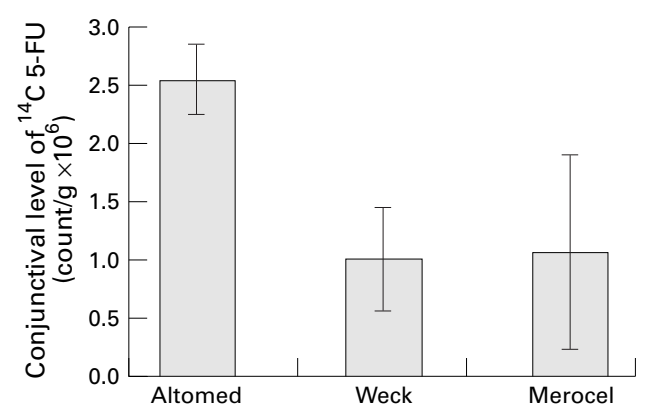

Figure 8 Conjunctival tissue level of ${ }^{14} \mathrm{C} 5$-FU following a single application using a Weck, Altomed, or Merocel sponge.

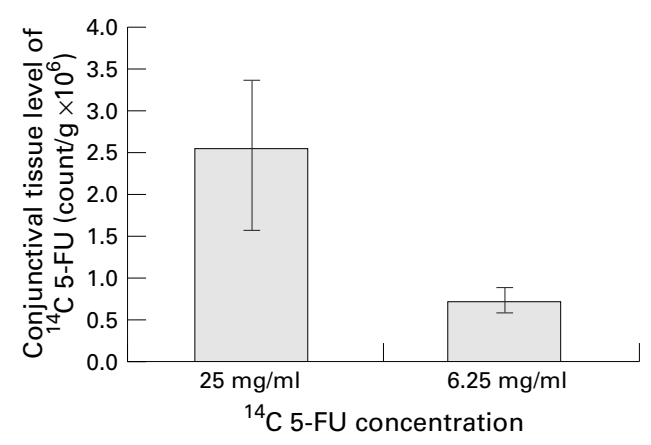

Figure 9 Conjunctival tissue level of ${ }^{14} \mathrm{C} 5-\mathrm{FU}$ following a single 5 minute application of an Altomed sponge soaked in either $25 \mathrm{mg} / \mathrm{ml}$ or $6.25 \mathrm{mg} / \mathrm{ml}^{14} \mathrm{C} 5-\mathrm{FU}$ solution.

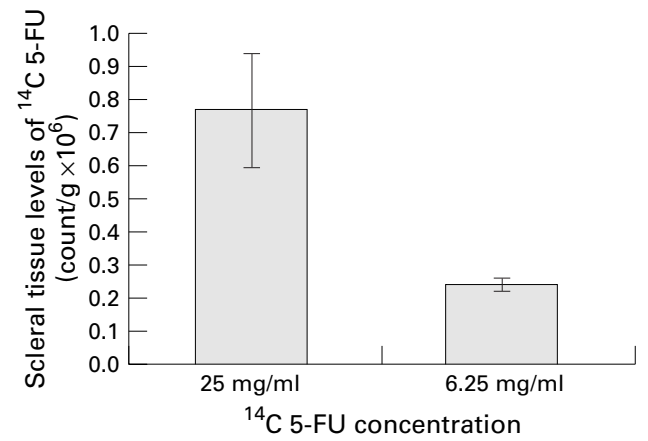

Figure 10 Scleral tissue level of ${ }^{14} \mathrm{C} 5-\mathrm{FU}$ following a single 5 minute application of an Altomed sponge soaked in either $25 \mathrm{mg} / \mathrm{ml}$ or $6.25 \mathrm{mg} / \mathrm{ml}^{14} \mathrm{C} 5-\mathrm{FU}$ solution.

\section{Discussion}

Clinicians have sought to titrate the dose of intraoperative antimetabolite delivered to tissues against a patient's risk of scarring following filtration surgery. The most commonly used methods for varying intraoperative antimetabolite delivery are to alter exposure time and antimetabolite concentration. A recent survey ${ }^{23}$ of antimetabolite use among American and Japanese glaucoma surgeons found a wide range in application time (0.5 seconds -7 minutes) and concentration (0.1$0.8 \mathrm{mg} / \mathrm{ml}$ ) of mitomycin $\mathrm{C}$ for the same clinical situation, with no clear logic for the choice in many cases. We have assessed the effect of varying multiple delivery variables on tissue levels of the antimetabolite 5-FU.

While to our knowledge there have been no animal studies looking at exposure time there have been two prospective studies on humans where intraoperative exposure time to an antimetabolite has been varied. Shin et $a l^{1415}$ 
Table 1 Summary of application techniques of intraoperative antimetabolites

\begin{tabular}{|c|c|c|c|c|c|}
\hline Study & $\begin{array}{l}M M C / \\
5-F U\end{array}$ & $\begin{array}{l}\text { Sponge Size } \\
\text { Stated }\end{array}$ & $\begin{array}{l}\text { Sponge make } \\
\text { specified }\end{array}$ & $\begin{array}{l}\text { Application } \\
\text { duration }\end{array}$ & $\begin{array}{l}\text { Application } \\
\text { technique notes }\end{array}$ \\
\hline Cohen $^{31}$ & MMC & $2 \times 5 \mathrm{~mm}$ & Cellulose & 2.5 minutes & $\begin{array}{l}\text { Excess liquid } \\
\text { mopped up with } \\
\text { second sponge }\end{array}$ \\
\hline Lamping $^{2}$ & MMC & No & Weck & 2.5 minutes & \\
\hline Smith $^{32}$ & $5-\mathrm{FU}$ & No & Cellulose & 5 minutes & \\
\hline Mora $^{33}$ & $5-\mathrm{FU}$ & No & $\begin{array}{l}\text { Weck or } \\
\text { instrument } \\
\text { wipe }\end{array}$ & 5 minutes & \\
\hline Madhavan $^{25}$ & MMC & No & No & 1-3 minutes & $\begin{array}{l}\text { Concentration } \\
\text { varied } 0.2-0.4 \\
\mathrm{mg} / \mathrm{ml}\end{array}$ \\
\hline Dreyer $^{34}$ & MMC & No & $\begin{array}{l}\text { Gelfoam, } \\
\text { Gelatin }\end{array}$ & 5 minutes & \\
\hline Greenfield $^{35}$ & MMC & $\begin{array}{l}\text { Surgical } \\
\text { spear }\end{array}$ & Weck & 5 minutes & \\
\hline Campagna $^{28}$ & MMC & No & Weck & $\begin{array}{l}3.5 \text { or } 5 \\
\text { minutes }\end{array}$ & $\begin{array}{l}\text { Time depends on } \\
\text { surgeon }\end{array}$ \\
\hline Mietz $^{18}$ & MMC & $4 \times 5 \times 1 \mathrm{~mm}$ & Geuder & 3-5 minutes & $\begin{array}{l}\text { MMC added to } \\
\text { dry sponge after } \\
\text { sponge placed on } \\
\text { eye }\end{array}$ \\
\hline $\operatorname{Joos}^{36}$ & MMC & No & $\begin{array}{l}\text { Alcon, } \\
\text { Cellulose }\end{array}$ & 5 minutes & \\
\hline Munden $^{24}$ & MMC & No & Cellulose & $\begin{array}{l}3.5 \text { or } 5 \\
\text { minutes }\end{array}$ & \\
\hline Lederer $^{26}$ & MMC & $4 \times 2 \times 1 \mathrm{~mm}$ & Cellulose & $2-5$ minutes & $\begin{array}{l}\text { Sponge irrigated } \\
\text { with saline } \\
\text { during } \\
\text { application }\end{array}$ \\
\hline Kupin $^{37}$ & MMC & $2 \times 3 \times 7 \mathrm{~mm}$ & Weck & 3 minutes & size when wet \\
\hline Lachkar $^{38}$ & 5-FU & $4.5 \times 4.5 \mathrm{~mm}$ & No & 5 minutes & \\
\hline Shin $^{15}$ & MMC & $2 \times 3 \times 7 \mathrm{~mm}$ & Cellulose & $\begin{array}{l}1,3,5 \\
\text { minutes }\end{array}$ & $\begin{array}{l}\text { Size when wet. } \\
\text { Comparison of } \\
\text { application times }\end{array}$ \\
\hline Costa $^{39}$ & MMC & $3 \times 2 \mathrm{~mm}$ & Weck-Cel & 3 minutes & \\
\hline Megevand $^{11}$ & MMC & $4.5 \times 4.5 \mathrm{~mm}$ & $\begin{array}{l}\text { Surgical } \\
\text { sponge }\end{array}$ & 2 or 5 mins & \\
\hline Chen $^{17}$ & MMC & No & Gelfoam & 5 minutes & $\begin{array}{l}\text { More than one } \\
\text { piece of sponge } \\
\text { used. Pieces } \\
\text { replaced every } \\
\text { minute }\end{array}$ \\
\hline Kitazawa $^{16}$ & MMC & No & Spongel & 5 minutes & $\begin{array}{l}0.2 \text { or } 0.02 \\
\mathrm{mg} / \mathrm{ml} \text { used }\end{array}$ \\
\hline Kitazawa $^{40}$ & MMC & No & Spongel & 5 minutes & \\
\hline Zacharia $^{7}$ & MMC & No & $\begin{array}{l}\text { Weck-cell or } \\
\text { Mentor O \& } \\
\text { O }\end{array}$ & $\begin{array}{l}3.5-7 \\
\text { minutes }\end{array}$ & $\begin{array}{l}\text { Either } 15 \text { or } 250 \\
\text { ml of irrigation } \\
\text { applied }\end{array}$ \\
\hline Robin $^{13}$ & MMC & No & Cellulose & 4 minutes & $\begin{array}{l}\text { Sponge replaced } \\
\text { after } 2 \text { minutes }\end{array}$ \\
\hline
\end{tabular}

randomised 174 patients undergoing trabeculectomy at the same time as cataract extraction to receive either no mitomycin or a 1,3 , or 5 minute intraoperative application of 0.5 $\mathrm{mg} / \mathrm{ml}$ mitomycin C. There was no significant difference in success rates between the control and mitomycin $\mathrm{C}$ groups, nor within the 1, 3, and 5 minute subgroups. Robin et $a l^{13}$ randomised phakic trabeculectomy patients to receive either placebo, $0.2 \mathrm{mg} / \mathrm{ml}$ mitomycin $\mathrm{C}$ for 2 minutes, $0.2 \mathrm{mg} / \mathrm{ml}$ mitomycin $\mathrm{C}$ for 4 minutes, or $0.4 \mathrm{mg} / \mathrm{ml}$ mitomycin $\mathrm{C}$ for $4 \mathrm{~min}$ utes. They found no significant difference in successful outcomes between the three application techniques for mitomycin C. However, no power calculation for detecting subgroup differences is quoted and it may well be that the study was not large enough to detect a difference. A retrospective review of cases $^{7}$ treated with mitomycin $\mathrm{C}$ for 3.5-7 minutes found that those patients treated for 3.5 minutes had less hypotony than those treated for longer. However a case-control study ${ }^{11}$ comparing 0.2 $\mathrm{mg} / \mathrm{ml}$ mitomycin $\mathrm{C}$ applied for either 2 or 5 minutes found no difference in success rates or complications. Table 1 highlights other case series that have included patients where the duration of intraoperative exposure to mitomycin C varied. ${ }^{18}{ }^{24-28}$ These studies have not analysed their results according to duration of exposure. In this study increasing the duration of application of a single ${ }^{14} \mathrm{C}$ 5-FU soaked sponge produces a dose-response curve with maximal scleral and conjunctival levels after 2-3 minutes. Beyond 1 minute there is a large variability in the amount of 5-FU delivered to tissues. The levels appear to plateau between 2 and 3 minutes with no significant increase in tissue concentration after this time. Greater variability was seen in the conjunctival tissue levels than in the scleral levels. This may be related to differences in the tissues themselves but may also be related to technique. In preparing a conjunctival flap the conjunctiva is stretched and may end up having a variable thickness. In contrast the sclera is largely untouched.

Human $^{13}$ and animal ${ }^{29}{ }^{30}$ studies have both used antimetabolite application regimens that involved replacing sponges. Chen's mitomycin $\mathrm{C}$ technique involves replacing sponges every minute. ${ }^{17}$ However, in no study have comparisons between a single sponge and replacing sponges been made. In our model replacing a sponge every minute for 5 minutes did not improve conjunctival and scleral levels compared with applying a single sponge for 5 minutes. Multiple replacement of a sponge may increase the risk of spreading antimetabolite onto non-targeted areas such as the conjunctival wound edge. Leaving a single soaked sponge may be adequate.

A study on a rabbit model of filtration surgery has looked at the effect of sponge area on bleb survival when $0.4 \mathrm{mg} / \mathrm{ml}$ mitomycin C is applied intraoperatively. ${ }^{21} \mathrm{~A}$ change in dry Weck-cell sponge size from $4 \times 2 \mathrm{~mm}$ to $8 \times 10$ $\mathrm{mm}$ produces an increase in bleb area, height, and survival. In contrast, our study shows that changing the size of an Altomed sponge from $3.5 \times 2 \mathrm{~mm}$ to $7 \times 4 \mathrm{~mm}$ does not improve the tissue levels of ${ }^{14} \mathrm{C} 5-\mathrm{FU}$ either at the application site or at the sites either side of the application point. It may well be that using live rabbits, an alternative antimetabolite, Weck sponges, and increasing the sponge size by a factor of 10 may produce a more significant effect. In this study the largest used sponge was $7 \times 4 \mathrm{~mm}$; this reflects the largest size sponge currently in use at Moorfields Eye Hospital. Reducing the area of this sponge by a factor of 10 would generate a tiny sponge that is not clinically relevant.

Two animal studies ${ }^{29}{ }^{30}$ have looked at the focality of intraoperative antimetabolite treatment. Both studies applied intraoperative 5-FU or mitomycin $\mathrm{C}$ between the sclera and conjunctiva of rabbits undergoing filtration surgery. In both papers $4 \times 1 \mathrm{~mm}$ Weck-cell sponges were used. Tissue biopsies taken from sites 90 and 180 degrees from the treated area and cultured for fibroblast outgrowth showed normal outgrowth. In one study ${ }^{30}$ it was pointed out that biopsies taken 90 degrees from the centre of the treatment area were only 1-2 $\mathrm{mm}$ from the edge of the treatment area. Clearly there is a rapid fall off in clinical effect 
when either 5-FU or mitomycin C is applied intraoperatively. Our findings confirm that there is a rapid fall off in tissue 5-FU levels either side of the treated area in this model and that treatment is relatively focal.

The papers listed in Table 1 have all used sponges to apply intraoperative antimetabolites. The brand used varies considerably while in many cases no brand is specified. Previous work has looked at the absorption and release of mitomycin C solution by four brands of surgical spear. $^{20}$ Merocel sponge spears were shown to absorb significantly more solution than the other brands that included Weck-cell but not Altomed. However, saturated Weckcell spears released more solution when placed on filter paper than did the other three. Our results compared three different sponge makes with the same dry cross sectional area and found that Altomed sponges deliver significantly more ${ }^{14} \mathrm{C} 5-\mathrm{FU}$ and with less variability than Weck-cell or Merocel sponges. This is important because if surgeons change sponges they may get different clinical effects depending on the sponge type used. Discussions with the manufacturers of Altomed sponges failed to yield any explanation for their delivery properties

In their review of American and Japanese clinical practice Chen et $a l^{23}$ showed that most surgeons altered application time rather than antimetabolite concentration between clinical situations. Two prospective studies ${ }^{13} 16$ have compared different mitomycin C concentrations applied for the same time. Neither found a difference in success rates. Both studies found that cataract progression was higher in the arm using a higher concentration of mitomycin C. A large case series ${ }^{18}$ compared patients receiving a 3-5 minute application of either $0.2 \mathrm{mg} / \mathrm{ml}$ or $0.5 \mathrm{mg} / \mathrm{ml}$ mitomycin C. No difference was found in IOP or complication rates. No studies have compared the effect of different concentrations of 5-FU. Our study shows that diluting the $25 \mathrm{mg} / \mathrm{ml}$ 5-FU solution by a factor of 4 significantly reduces the conjunctival levels by a factor of 4 . Our study suggests that it may be more logical to vary concentrations rather than delivery time. Delivery times less than 2-3 minutes are on the exponential part of the uptake curve and may therefore give rise to large variability in delivery.

Consistently successful surgery requires the control of as many variables as possible. Papers describing the application of intraoperative antimetabolites usually mention antimetabolite concentration and application time. Our work confirms that these variables are important in determining tissue delivery of 5-FU, although applying a sponge soaked in 5-FU beyond 3 minutes is unlikely to be useful. The lesser quoted and variable (Table 1) properties of types of sponge can alter tissue delivery by as much as $100 \%$. Our study has limitations because it was carried out on cadaver eyes. We would not expect the uptake of drug to be very dissimilar in a live animal because of the limited blood flow in the tissues involved.
Understanding the effect that particular application factors have, allows the ophthalmologist to have more control on the amount of antimetabolite delivered to tissues. This should give more reproducible results in the same clinical situation while permitting the dose delivered in high risk cases to be better controlled. If studies from different centres are to be compared then it is important that delivery variables are standardised.

Financial interest: None of the authors had any commercial or proprietary interest in any of the products discussed in the article.

Supported by MRC Grant G9330070, International Glaucoma Association.

Presented in part at the Association for Research in Vision Presented in part at the Association for Research in Vision
and Ophthalmology Meeting, Fort Lauderdale, Florida, 1997.

1 The Fluorouracil Filtering Surgery Study Group. Five-year follow-up of the Fluorouracil Filtering Surgery Study. $A m \mathcal{F}$ Ophthalmol 1996;121:349-66.

2 Lamping KA, Belkin JK. 5-Fluorouracil and mitomycin C in pseudophakic patients. Ophthalmology 1995;102:70-5.

3 Gandolfi SA, Vecchi M. 5-fluorouracil in combined trabeculectomy and clear-cornea phacoemulsification with posterior chamber intraocular lens implantation. A oneyear randomized, controlled clinical trial. Ophthalmology 1997;104:181-6.

4 Egbert PR, Williams AS, Singh K, et al. A prospective trial of intraoperative fluorouracil during trabeculectomy in a black population. Am $\mathcal{F}$ Ophthalmol 1993;116:612-6.

5 Costa VP, Wilson RP, Moster MR, et al. Hypotony maculopathy following the use of topical mitomycin C in glaucoma filtration surgery. Ophthalmic Surg 1993;24:389glau.

6 Shields MB, Scroggs MW, Sloop CM, et al. Clinical and histopathologic observations concerning hypotony after trabeculectomy with adjunctive mitomycin C. Am f Ophthalmol 1993;116:673-83.

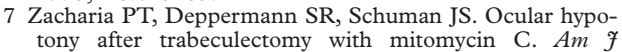
Ophthalmol 1993;116:314-26.

8 Caronia RM, Liebmann JM, Friedman R, et al. Trabeculectomy at the inferior limbus. Arch Ophthalmol 1996;114: 387-91.

9 Greenfield DS, Suner IJ, Miller MP, et al. Endophthalmitis after filtering surgery with mitomycin. Arch Ophthalmol 1996;114:943-9.

10 Higginbotham EJ, Stevens RK, Musch DC, et al. Blebrelated endophthalmitis after trabeculectomy with mitomycin C. Ophthalmology 1996;103:650-6.

11 Megevand GS, Salmon JF, Scholtz RP, et al. The effect of reducing the exposure time of mitomycin $\mathrm{C}$ in glaucoma filtering surgery. Ophthalmology 1995;102:84-90.

12 Wolner B, Liebmann JM, Sassani JW, et al. Late bleb-related endophthalmitis after trabeculectomy with adjunctive 5-fluorouracil. Ophthalmology 1991;98:1053-60.

13 Robin AL, Ramakrishnan R, Krishnadas R, et al. A long-term dose-response study of mitomycin in glaucoma filtration surgery. Arch Ophthalmol 1997;115:969-74.

14 Shin DH, Simone PA, Song MS, et al. Adjunctive subconjunctival mitomycin $\mathrm{C}$ in glaucoma triple procesubconjunctival mitomycin C in glau
dure. Ophthalmology 1995;102:1550-8.

15 Shin DH, Hughes BA, Song MS, et al. Primary glaucoma triple procedure with or without adjunctive mitomycin. Prognostic factors for filtration failure. Ophthalmology 1996;103:1925-33.

16 Kitazawa Y, Suemori Matsushita H, Yamamoto T, et al. Low-dose and high-dose mitomycin trabeculectomy as an initial surgery in primary open-angle glaucoma. Ophthalmology 1993;100:1624-8.

17 Chen CW, Huang HT, Bair JS, et al. Trabeculectomy with simultaneous topical application of mitomycin-C in refractory glaucoma. F Ocul Pharmacol 1990;6:175-82.

18 Mietz H, Krieglstein GK. Short-term clinical results and complications of trabeculectomies performed with mitomycin C using different concentrations. Int Ophthalmol mycin C using

19 Kawase K, Matsushita H, Yamamoto T, et al. Mitomycin concentration in rabbit and human ocular tissues after topical administration. Ophthalmology 1992;99:203-7.

20 Flynn WJ, Carlson DW, Biffano SL. Mitomycin trabeculectomy: the microsurgical difference. F. Glaucoma 1995;4:86-90.

21 Cordeiro MF, Constable PH, Alexander RA, et al. Effect of varying the mitomycin-C treatment area in glaucoma filtration surgery in the rabbit. Invest Ophthalmol Vis Sci 1997;38:1639-46.

22 Shin DH, Reed SY, Swords RC, et al. Cellulose sponge punch for controlled mitomycin application. Arch Ophthal-

23 Chen PP, Yamamoto T, Sawada A, et al. Use of antifibrosis agents and glaucoma drainage devices in the American and Japanese glaucoma societies. F Glaucoma 1997;6:192-6. 
24 Munden PM, Alward WL. Combined phacoemulsification, posterior chamber intraocular lens implantation, and trabeculectomy with mitomycin C. Am f Ophthalmol 1995;119: 20-9.

25 Madhavan $\mathrm{HN}$, Rao SB, Vijaya L, et al. In vitro sensitivity of human Tenon's capsule fibroblasts to mitomycin $\mathrm{C}$ and its correlation with outcome of glaucoma filtration surgery. Ophthalmic Surg 1995;26:61-7.

26 Lederer CM Jr. Combined cataract extraction with intraocular lens implant and mitomycin-augmented trabeculectomy. Ophthalmology 1996;103:1025-34.

27 Costa VP, Moster MR, Wilson RP, S et al. Effects of topical mitomycin $\mathrm{C}$ on primary trabeculectomies and combined procedures. Br 7 Ophthalmol 1993;77:693-7.

28 Campagna JA, Munden PM, Alward WL. Tenon's cyst formation after trabeculectomy with mitomycin C. Ophthalmic Surg 1995;26:57-60.

29 Khaw PT, Doyle JW, Sherwood MB, et al. Prolonged localized tissue effects from 5 -minute exposures to fluorouraci and mitomycin C. Arch Ophthalmol 1993;111:263-7.

30 Khaw PT, Sherwood MB, Doyle JW, et al. Intraoperative and post operative treatment with 5-fluorouracil and mitomycin-C: long term effects in vivo on subconjunctival mitomycin-C: long term effects in vivo on subconjunctivi

31 Cohen JS, Greff LJ, Novack GD, et al. A placebo-controlled, double-masked evaluation of mitomycin $\mathrm{C}$ in combined glaucoma and cataract procedures. Ophthalmology 1996; 103:1934-42.
32 Smith MF, Sherwood MB, Doyle JW, et al. Results of intraoperative 5-fluorouracil supplementation on trabeculecoperative 5-fluorouracil supplementation on trabeculectomy for

33 Mora JS, Nguyen N, Iwach AG, et al. Trabeculectomy with intraoperative sponge 5-fluorouracil. Ophthalmology 1996; 103:963-70

34 Dreyer EB, Chaturvedi N, Zurakowski D. Effect of mitomycin C and fluorouracil-supplemented trabeculectomies on the anterior segment. Arch Ophthalmol 1995;113:578-80.

35 Greenfield DS, Miller MP, Suner IJ, et al. Needle elevation of the scleral flap for failing filtration blebs after trabeculec-
tomy with mitomycin C. Am $\mathcal{F}$ Ophthalmol 1996;122:195204.

36 Joos KM, Bueche MJ, Palmberg PF, et al. One-year follow-up results of combined mitomycin C trabeculectomy and extracapsular cataract extraction. Ophthalmology 1995;102(1):76-83.

37 Kupin TH, Juzych MS, Shin DH, et al. Adjunctive mitomycin C in primary trabeculectomy in phakic eyes. Am $\mathcal{F} O p h-$ in $C$ in primary trabecul

38 Lachkar Y, Leyland M, Bloom P, et al. Trabeculectomy with intraoperative sponge 5-FU in Afro-Caribbeans. $\mathrm{Br} \mathcal{F} \mathrm{Oph}$ thalmol 1997;81:555-8.

39 Costa VP, Comegno PE, Vasconcelos JP, et al. Low-dose mitomycin C trabeculectomy in patients with advanced glaucoma. F Glaucoma 1996;5:193-9.

40 Kitazawa Y, Kawase K, Matsushita $\mathrm{H}$, et al. Trabeculectomy Arch Ophthalmol 1991;109:1693-8. 